\title{
Intervention Programs for Spanish Inmate Aggressors Convicted of Domestic Violence
}

\author{
Luis Millana* \\ Research Group on Sociopsychobiology of Aggression, Complutense University of Madrid, Spain
}

\begin{abstract}
Following the enactment of the Organic Law 1 / 2004 on comprehensive protection measures against gender violence, intervention programs for both batterers serving in prison who later access to a semi-free period and for those with suspension of the sentence enforcement who work in community services have become necessary. Herein, we describe, maintain, and go further in rehabilitation of batterers in order to prevent further episodes of violence and protect and guarantee battered women's safety.
\end{abstract}

Keywords: Penitentiary, prison, domestic violence, batterer, intervention programs, maltreatment.

\section{INTRODUCTION}

Domestic violence is not a new phenomenon in democratic societies, but today is considered one of the most prominent and worrying social problems. It is defined as any behavior within an intimate relationship in which one partner causes physical, emotional or sexual damage to the other partner. Domestic violence has been shown not to correlate with the social, economic, educational, cultural or religious background of the aggressor or the victim. It is overwhelmingly suffered by women; however, there are other forms of domestic violence that affect both heterosexual and homosexual men though to a far lesser extent. In 1993, the General Assembly of the United Nations released a statement on the elimination of violence against women, and in 1995 the Fourth United Nations World Conference on Women stated that violence suffered by women represents an important obstacle to achieve the objectives of global equality, development and peace in the world, and established the eradication of this type of violence as a top priority. In 1997, the World Health Organization (WHO) conducted a multicountry study on women's health and domestic violence against women (United Nations, 1993, 1995, World Health Organization, 2005), and in 1998 this institution stated that domestic violence is an international priority and a major public health problem.

From 2007 to present, in Spain formal complaints have increased by $2.7 \%$ from 29,277 cases in the first quarter of 2007 up to 32,492 in the first quarter of 2010. Between January and June 2010 there were 13,919 criminal trials for gender violence (i.e. domestic violence in which the female partner is the victim), and $59.3 \%$ of these trials have ended up in a conviction (Spanish Ministry of Equality, 2010). Of the formal complaints reported to the police in the first quarter of 2010, 72.6\% was reported by Spanish women and $27.4 \%$ by foreign women living in Spain, with a dramatic drop of formal complaints reported by the latter. Also, from

*Address correspondence to this author at the Research Group on Sociopsychobiology of Aggression, Complutense University of Madrid, Spain; Tel: +34609018284; E-mail: 1c_millana_c@yahoo.es
January 2003 to October 2010 there were 529 fatalities (Ministerio de Sanidad, Political Social e Igualdad, Spain, 2010, 2010a, Sanmartín et al., 2010). On the other hand, the results from the large-scale survey conducted in Spain by the Women Institute (Instituto de la Mujer, 2006) enable us to calculate the burden of domestic violence and distinguish those women who answered "sometimes" at least to 13 statements in the survey, which reflected 6 different types of violence or abuse, of the 26 statements from which the data were gathered, from those women who self-classified as maltreated because they were frequently battered by their male partners. In order words, this survey enables us to distinguish self-reported maltreatment from technical maltreatment (see Table 1). According to the survey results, $3.6 \%$ of women aged 18 or older reported having been abused or battered during the last year by somebody living in their household or a boyfriend who did not live with the respondent. This percentage represents a total of 677,352 women out of $18,606,347$ of women living in Spain aged 18 or older. Also, $9.6 \%$ of women living in Spain aged 18 or older are considered "technically" maltreated, which roughly represents a total of $1,786,978$. As their main goal, penitentiary institutions are entrusted by the current Spanish legislation with "rehabilitation and social reintegration of people sentenced to criminal penalties and imprisonment, and the retention and custody of detainees, prisoners and convicts" as well as the support and assistance for welfare of both inmates and freed people. In turn, the Penitentiary Regulations state that prison administration "should design training programs aimed at developing the inmates' skills in order to address those specific problems that may have influenced their previous criminal behavior and enhance and facilitate contacts with the community outside the prison (...)". Therefore, in Spain, the penitentiary administration is responsible for carrying out specific programs for individuals serving in prison convicted of crimes who have been involved in gender violence (Ley Orgánica 1/1979, Real Decreto 190/1996, Ley Orgánica 1/2004).

The aim of this paper is to provide a review of psycotherapy-oriented treatment currently conducted in Spanish prisons for batterer inmates. We describe both the intervention 
Table 1. Questions in the Large Scale Survey on Violence against Women (Spain Women Institute, 2006)

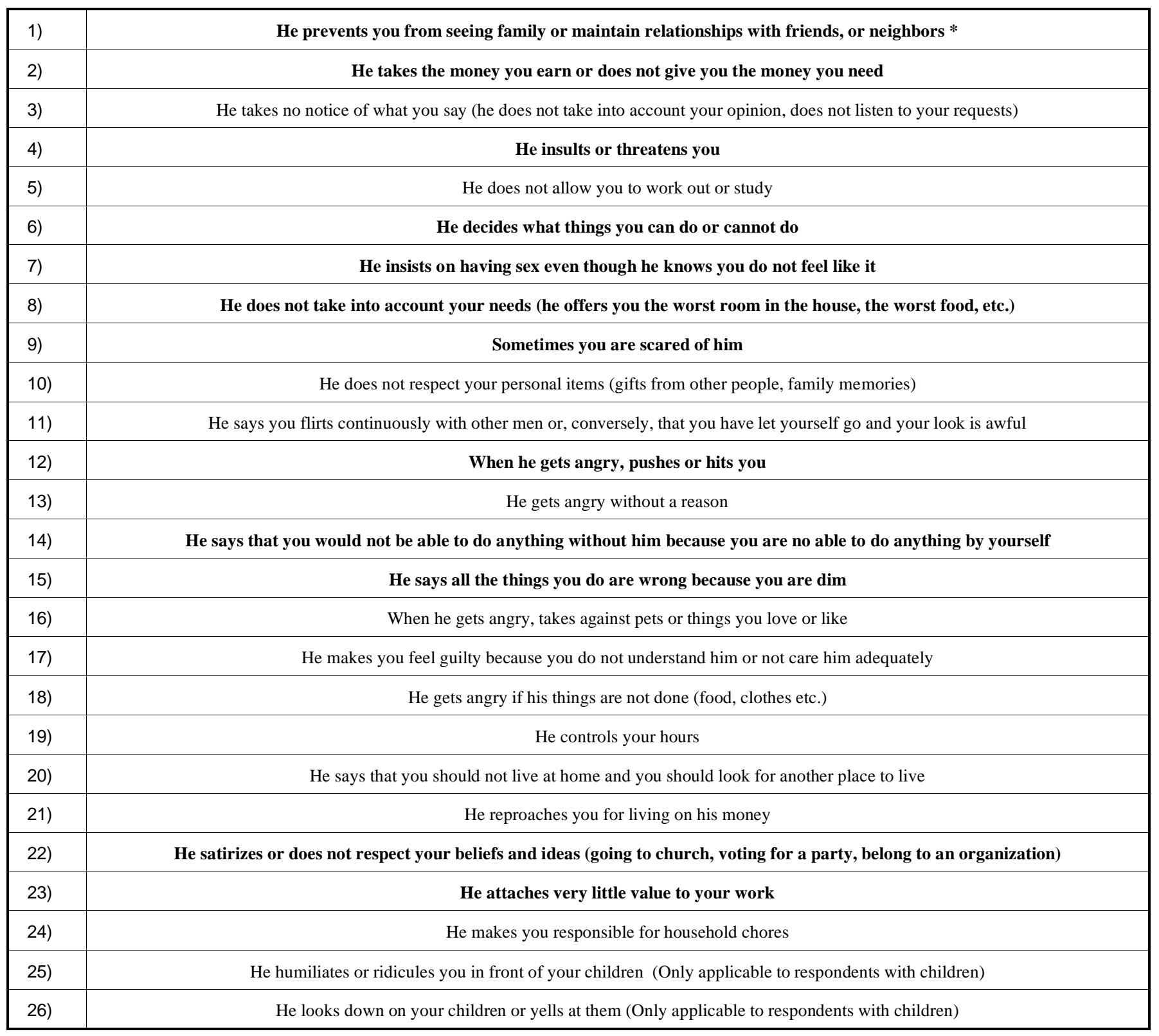

*Behaviors used to detect technical abuse are in bold

programs conducted inside the prisons and those targeted to batterers whose sentences have been suspended under the condition that the batterer promises undergo this type of treatment (court-mandated intervention). Therefore, the latter interventions are conducted outside the prison and are to be considered as an alternative to standard imprisonment.

\section{AGGRESSOR PROFILE}

There is not an accurate profile of the common psychological characteristics of battered women, and individuals who abuse or batter are not all alike and do not have a specific psychopathological traits that enable us to detect them in advance. However, there are some common unspecific characteristics of batterers and abusers men, such as lack of coping skills, low self-esteem, need for dominance, hostility, impulsivity, social isolation, lack of assertiveness, depend- ence and insecurity, cognitive rigidity, depression, anxiety, jealousy, possessiveness, traditional role performance, greater likelihood of alcohol and other drugs use or abuse compared to the general population, and witnessing physical abuse within families during childhood (Russell et al.,1989; Dutton et al., 1996; Quinteros \& Carbajosa, 2008). Thus, Dutton and Golant (1997) distinguished three types of aggressors: psychopathic, hypercontrolled and cyclic / emotionally unstable. In turn, Jacobson and Gottman (2001) classified aggressors into two categories: "cobras" and "pitbulls". In Spain, Echuburúa, De Corral and Amor (1999) take into account two variables: the setting in which violence takes place and the psychopathological profile of the aggressor. These authors has put forward two situations: (1) violence only at home and (2) violence in any setting; and two types of aggressor according to their psychopathological 
profile: aggressors with deficits in interpersonal skills and those lacking impulse control (see Table 2). Also in Spain, Madina (1994) and Pérez del Campo (1995) have stressed the importance of traditional values that have been internalized through positively enhanced behaviors, such as strength, self-reliance, rationality and constant control of the milieu. Aggressors usually consider these values and the associated behaviors as "male-mature and superior" in comparison to other values and behaviors considered as being "female-inmature and inferior". In these circumstances, the aggressor uses violence to regain the self-perceived lost control in the only environment in which he can prove or justify their superiority over his partner: their own home.

Table 2. Characteristics of Abusive Men

\begin{tabular}{|c|c|}
\hline Area & Feature \\
\hline \multirow{5}{*}{ Behavioral } & Social desirability / "double facade" \\
\hline & History of violence in previous couples \\
\hline & Resistance to change \\
\hline & Substance Abuse \\
\hline & Degree and type of impulse control \\
\hline \multirow{7}{*}{ Cognitive } & Personalization / generalization \\
\hline & $\begin{array}{l}\text { Rigid definition of masculine and feminine roles, } \\
\text { beliefs, values, behaviors, etc. }\end{array}$ \\
\hline & Denial, minimization and justification \\
\hline & Liability externalization \\
\hline & Lack of empathy \\
\hline & Rumination \\
\hline & Personalization / generalization \\
\hline \multirow{5}{*}{ Emotional } & Low self-esteem \\
\hline & Emotional restraint and rationalization of feelings \\
\hline & Dependency / insecurity \\
\hline & Jealousy \\
\hline & Low tolerance to frustration \\
\hline \multirow{6}{*}{ Interactional } & Isolation \\
\hline & Controlling and possessive behavior \\
\hline & $\begin{array}{l}\text { Inability to resolve conflicts in a nonviolent way at } \\
\text { home }\end{array}$ \\
\hline & $\begin{array}{l}\text { Avoidance and denial of conflicts in the environment } \\
\text { outside the family }\end{array}$ \\
\hline & Poor communication skills \\
\hline & Low assertiveness \\
\hline
\end{tabular}

Source:Quinteros et al., 2008.

\section{INTERVENTION PROGRAMS TARGETED TO BATTERERS SERVING IN PRISON}

As of December 2009, the number of batterers serving in Spanish prisons amounted to 4,734. Of these, 2,320 (49\%) were serving solely because of a domestic violence sentence. The remainder was imprisoned also due to other offenses aside from gender violence. By age, the largest group was between 41 and 50 years old (66.5\%), followed by the group between 31 and 40 years old. The average age of batterers was 39 years. Of individuals serving in prison due to domestic violence, in $34.2 \%$ physical abuse had been the main offense. Concerning telematically monitored electronic devices to keep batterers away from their victims, as of 31 December 2009,157 of these devices were operational. After the Spanish Organic Law 1 / 2004 on comprehensive protection measures against gender violence came into force, intervention programs for batterers have become essential tools for intervention both within and outside prisons to enforce the terms in the sentences pronounced by Spanish judges. This law envisages the variety and, therefore, difficulty of the multilevel approach, and indicates that combined efforts should be made on several fronts, such as educational activities at schools, high schools and Universities, preventive measures, comprehensive care for the victim and both civil and criminal actions. It has been demonstrated that programs of replacement or suspension of custodial sentences by community services and participation in intervention programs (court-mandated) in those cases in which the sentence is shorter than two years is efficacious in the case of batterers (Simon, 1995). The first programs were conducted in the United States in the late 1970s, and they were feminismoriented, since feminists were the promoters of these programs. These women thought that the return of the victim to home was not the best solution (Feder, Wilson \& Austin, 2008). Initially, educational group therapy was used. Then, techniques focused on social skill development and the cognitive-behavioral approach, which at present are the two most frequently used theoretical orientations, were introduced (Redondo \& Garrido, 1999). Currently, treatment approaches can be classified into five types: cognitivebehavioral, systemic, ventilation, insight-oriented and feminist-oriented, though in the practice components from these five approaches are used in conjunction with predominance of the cognitive / behavioural point of view. These intervention programs seek violent men take on liability for their behavior, suppress the rationalizations and justifications they use to explain their behavior and admit liability for their abuses. Likewise, most programs also include components designed to meet the need to control anger and stress and develop communication skills (Medina, 2002; Lila et al., 2010). Currently, in Spanish prisons two main programs are used: (1) Batterer Intervention Program on Gender Violence (Spanish abbreviation: PRIA) and (2) Prison Program for Men Who Have Committed Violence against Women (Castillo et al., 2005; Ruiz et al., 2010; Asociación de mujeres por la inserción laboral (SURT), 2007)

\section{Batterer Intervention Program on Gender Violence (PRIA)}

The origin of this intervention program dates back to 2001 and 2002. In those years, a sample of 52 men convicted of gender violence was treated with a scheme similar to that 
proposed by Echeburúa (Echeburúa \& De Corral, 1998; Echeburúa, Amor \& Fernández-Montalvo, 2007). In 2004, the intervention program was reviewed and updated. As a result, the handbook In-Prison Treatment Program for Aggressors in the Family Environment was published. This handbook focused on individuals serving in prison who had committed violent domestic offenses. The intervention envisaged in the handbook consisted of 44 group-format sessions (1 year) and underscored the emotional aspects within the framework of the cognitive /behavioral and clinical approaches. For the group sessions, there was a set of 12 modules that were addressed consecutively: (1) taking on liability, (2) defense mechanisms, (3) identification and expression of emotions, (4) empathy toward the victim, (5) cognitive distortions and irrational beliefs, (6) controlling emotions (anxiety, jealousy, anger, and resentment), (7) interpersonal relationships and communication skills, (8) problem solving strategies, (9) sexual education, (10) self-esteem, (11) positive lifestyle, and (12) relapse prevention (Castillo et al., 2005). After the Spanish organic law on comprehensive protection measures against gender violence and the subsidiary royal decree that states the replacement or suspension of custodial sentences by community services or interventional program attendance came into effect, it became essential to provide prisons with sufficient staff and material resources to implement this intervention program not only for batterers serving in prison, but also for those who have accepted the regimen of semi-freedom, community services or intervention program attendance (Ley Orgánica I/2004; Real Decreto 1849/2009; Real Decreto 1849/2009). Therefore, it was necessary to develop new strategies and interventional procedures in order to integrate clinical and genderperspective aspects and address psychological intervention for aggressors with different profiles and different legal and penitentiary status. Thereby, it was developed the intervention program called Gender violence: Aggressor Intervention Program, which presents a series of novel features compared to the former program: new therapeutic approaches in each unit and deeper development of the psychological aspects of violence and power, control and leadership. In addition, new units on sexual violence, gender perspective and involvement of children as victims of violence were added. Also, a special emphasis on the need to address motivation for treatment and relapse prevention was placed. Part I (units 15) addresses clinical factors that the inmate must work before beginning with the analysis of violent behaviour. Part II (units 6-11) addresses different manifestations of violence: physical, psychological and sexual aspects of violence and psychological manipulation of children. At the end, there are two additional modules: education on gender differences and relapse prevention. The program length varies from 6 months to 1 year, depending on a number of factors, such as inmate's profile, relapse or recidivism risk level, sentence duration, circumstances under which the program is conducted, and inmate's improvement. The number of sessions ranges from 25 (basic program) to 50 (intensive program). When the program is used to replace the standard imprisonment, initially there are 25 compulsory attendance sessions. The format is either individual o collective (group therapy), generally closed, with a maximum number of 12 participants per session and weekly sessions (Ruiz et al., 2010) (see Table 3).

\section{VIDO Penitentiary Program (Conducted in Prisons Under the Jurisdiction of the Catalonia Government)}

This program stems from the need to treat separately domestic violence aggressors and those who had committed violent offenses not related to home or family relationships. It is based on two principles: 1) inmates cannot be treated in the same way as individuals living in the community, and 2) the role played by the facilitators is essential. The program is based on the cognitive-behaviorial model, and the intervention is either individual or group or familial. Deficits underlying violent behavior are the main focus with emphasis placed on the generalization of learning from the stage of detention or suspension of sentence until the stage of community supervision. It consists of 17-20 sessions distributed in 3 steps. Step 1 addresses awareness and liability. Step 2 addresses gender inequality and roles, attributions, and empathy. Step 3 addresses conflict solving strategies, affect and emotion expression within interpersonal relationships and how to set limits within the relationship. The recommended format is a closed group work (maximum: 15 inmates), wherein participants can engage each other in dynamic interaction, with opportunities for individual sessions as a reinforcement of the group intervention at the start and the end of the group program. Exceptionally, an inmate can apply for an individual session at any time in the course of the program. Individual intervention is performed in those cases in which group intervention is contraindicated (e.g. aggressors who present with learning difficulties). The number of participants ranges between 6 and 12 on a weekly basis with a duration of 1.5-2 hours per session. There are several versions of this program, such as the short intensive program (34 months) and the long intensive program (9-12 months) (Asociación de mujeres por la inserción laboral (SURT), 2007; Martínez García \& Pérez Ramírez, 2009) (see Table 4).

Generally, both the Batterer Intervention Program on Gender Violence (PRIA) and the VIDO Penitentiary Program are targeted to individuals convicted of gender violence that do not present a non-treated active substance abuse problem, severe psychopathological disorder, low intellectual capacity or poor understanding of the language. Exclusion criteria are poor attendance and disruptive behavior during the intervention. Voluntary participation in the program is recommended.

Loinaz et al., (2009, 2010a, 2010b) suggest the need to adapt intervention programs to the different subtypes of aggressors encountered in Spanish prisons. Following Holtzworth-Munroe typology, these authors describe the characteristics of each subtype and make treatment recommendations to best fit the characteristics of the different subtypes (Holtzworth-Munroe \& Stuart, 1994; Holtzworth-Munroe et al., 2000) (see Table 5). They recommend a three modulebased intervention program as follows: (1) motivation for therapy (liability, awareness, insight and empathy), (2) intervention (divided into three sections: the cycle of violence, cognitive distortions and emotional control; self-esteem, jealousy and healthy lifestyle; and assertiveness, communication and problem solving), and (3) relapse prevention (risk identification and coping skill development). In the short version, the emphasis is placed on emotional aspects, while 
Table 3. Batterer Intervention Program on Gender Violence (PRIA Program), Secretary General of Prisons (2009)

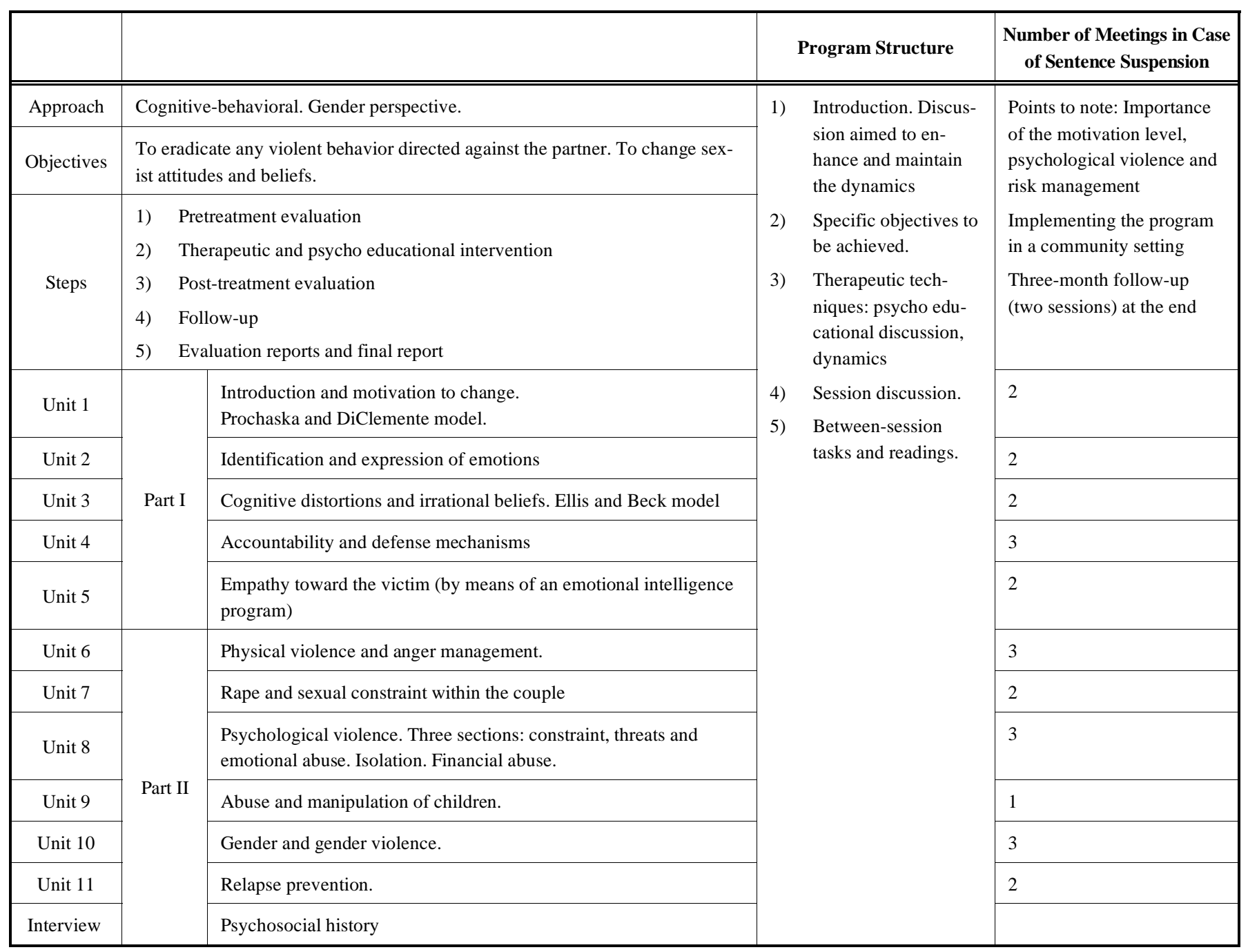

Table 4. In-Prison Program for Men who have Committed Violence against Women, Department of Catalonia Government (2007) (Vido Program)

\begin{tabular}{|c|c|c|c|c|c|}
\hline & & & & & Program Structure \\
\hline Objectives & \multicolumn{4}{|c|}{$\begin{array}{l}\text { The overall objective of the intervention program is to stop the violence exerted by the aggressors against his } \\
\text { partner within couple in relationships and provide them with alternatives to violence to manage and work out } \\
\text { problems and conflicts. } \\
\text { Starting the process for masculinity development from the point of view of the gender equity model } \\
\text { Accept liability for violent behavior } \\
\text { Promote and encourage non-violent strategies tailored for solution of conflicts. }\end{array}$} & \multirow{6}{*}{$\begin{array}{l}\text { Share concerns, feel- } \\
\text { ings, stories that } \\
\text { affect the time. } \\
\text { Working with specific } \\
\text { dynamics specific } \\
\text { content. } \\
\text { Share thoughts, } \\
\text { feelings, etc. }\end{array}$} \\
\hline Approach & \multicolumn{4}{|c|}{ Cognitive-behavioral approach } & \\
\hline \multirow[t]{4}{*}{ Steps } & \multicolumn{4}{|c|}{$\begin{array}{l}\text { Evaluation: Detection of changes in participants' behavior and attitudes. Special emphasis: satisfaction level (test } \\
\text { administered in the last session), gender role expectations, liability level for violent behavior (pre-test, post-test) }\end{array}$} & \\
\hline & \multicolumn{2}{|c|}{ Intake interviews } & \multirow{3}{*}{ 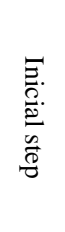 } & Session I: introduction & \\
\hline & \multirow{2}{*}{$\begin{array}{l}\text { Group } \\
\text { sessions }\end{array}$} & $\begin{array}{l}\text { Initial step: awareness } \\
\text { and liability }\end{array}$ & & Session II: In-depth look at the issue of violence & \\
\hline & & $\begin{array}{l}\text { Middle step: } \\
\text { deconstruction }\end{array}$ & & Session III-VI: Reconstruction of violence & \\
\hline
\end{tabular}




\begin{tabular}{|c|c|c|c|c|}
\hline & \multirow[b]{3}{*}{ Chance for individual sessions } & \multirow{5}{*}{ 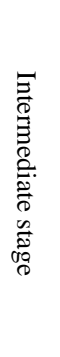 } & Session VII: Liability of men and women & \\
\hline & & & Session VIII: Gender roles as a social construction & \\
\hline & & & Session IX: Unequal power-based relationships & \\
\hline & Closing: final interview & & Session X: Empathy to people who have suffered violence & \\
\hline & & & Session XI: Causes and myths of violence & \\
\hline & & 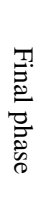 & $\begin{array}{l}\text { Sessions XII-XIII: Expectations and needs in interpersonal } \\
\text { relationships. }\end{array}$ & \\
\hline Duration & \multicolumn{3}{|c|}{17 to 20 sessions } & \\
\hline Format & \multicolumn{3}{|r|}{ Group } & \\
\hline Groups & \multicolumn{3}{|r|}{ Closed } & \\
\hline Duration & \multicolumn{3}{|c|}{$\begin{array}{c}\text { In the history interview, general information is collected. In the psychosocial interview information, } \\
\text { crime-related information is collected }\end{array}$} & \\
\hline
\end{tabular}

Table 5. Characteristics of Batterer Subtypes and Therapeutic Guidelines (Loinaz, 2010)

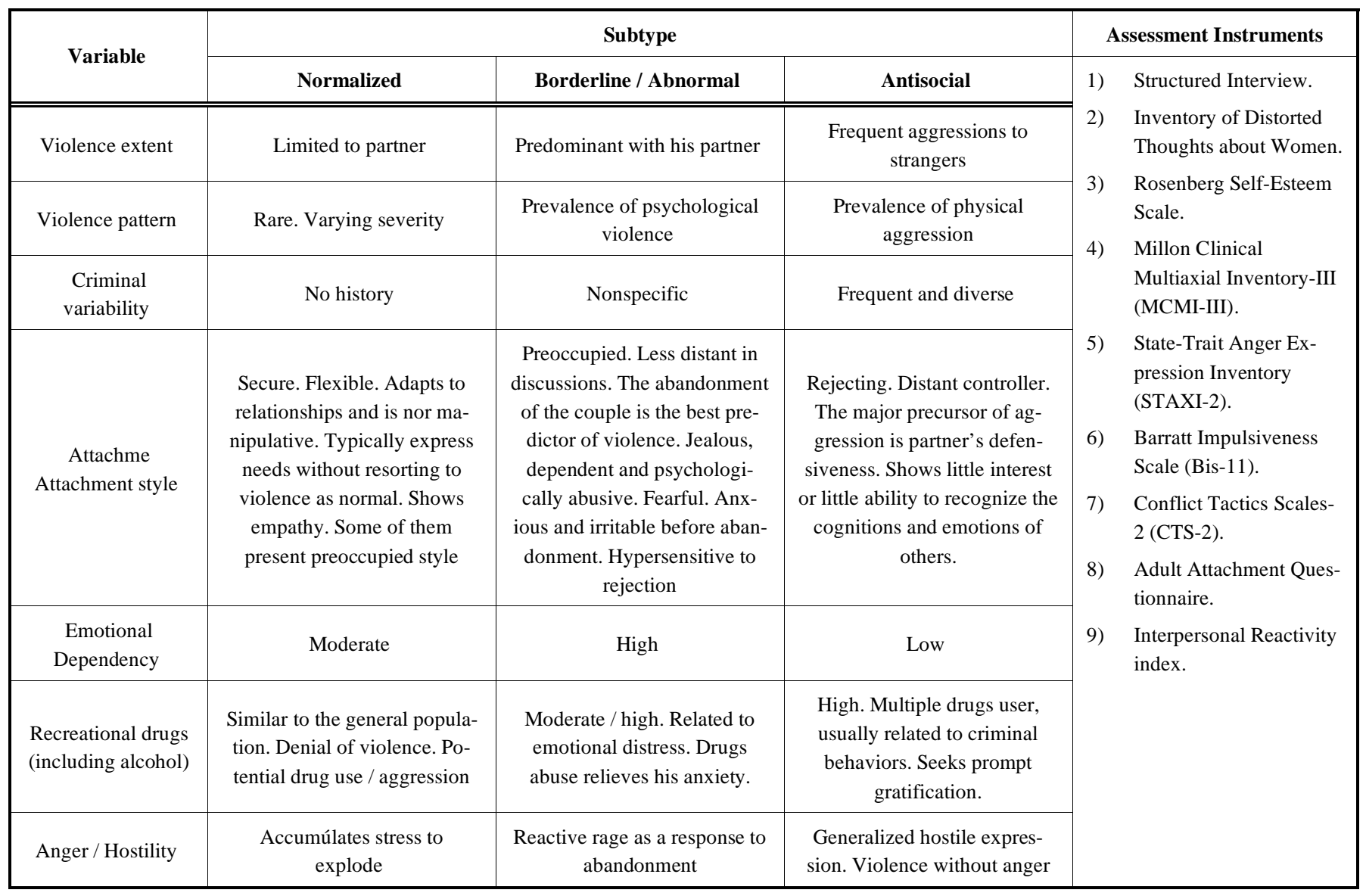




\begin{tabular}{|c|c|c|c|}
\hline \multirow{2}{*}{ Variable } & Normalized & Borderline / Abnormal & Antisocial \\
\cline { 2 - 4 } Personality & $\begin{array}{c}\text { Dependent, passive- } \\
\text { aggressive, avoidant }\end{array}$ & Borderline & Antisocial and narcissistic \\
\hline \hline Risk & Low & Intermediate & High \\
\hline \multirow{2}{*}{$\begin{array}{c}\text { Therapeutic } \\
\text { guidelines }\end{array}$} & $\begin{array}{c}\text { Short programs focused on the } \\
\text { appropriate expression of } \\
\text { emotions and anger manage- } \\
\text { ment. Assess the need for drug } \\
\text { use treatment }\end{array}$ & $\begin{array}{c}\text { Intermediate-long programs. } \\
\text { Special emphasis on interper- } \\
\text { sonal interactions / attachment } \\
\text { and anxious or depressive } \\
\text { psychopathology. Assess need } \\
\text { for drug abuse treatment }\end{array}$ & $\begin{array}{c}\text { Long programs. Highly struc- } \\
\text { tured, directive and focused on } \\
\text { the negative consequences of } \\
\text { their behavior. Need for drug } \\
\text { abuse treatment is usual }\end{array}$ \\
\hline
\end{tabular}

the long version fundamentally addresses cognitive distortions, changing violent behavior, anger and impulsivity and liability. Because drug abuse, including alcohol, plays an important role and directly or indirectly impacts in intimate partner violence (Dutton et al., 1997; Ortiz \& Garcia, 2003; Stuart et al., 2008; Jewell \& Wormith, 2010), an evaluation of substance-related problems is carried out, but treatment, if necessary, is performed externally. The format is based on group sessions, but, if required, participants can benefit from individual sessions. Also, a pre and post-intervention evaluation is conducted and various psychological variables are monitored during the program.

\section{INTERVENTION PROGRAMS TARGETED TO BATTERERS WITH SENTENCE SUSPENSION (COURT-MANDATED INTERVENTION)}

Intervention for aggressors who are serving in prison does not cover the whole extent of the problem. In Spain, suspension of the execution of the sentence ordered by a judge is becoming increasingly common in the case of primary and normalized offenders, that is, those who have been convicted of a new offense and, therefore, are not recidivist (Arce \& Fariña, 2007; Lila et al., 2010). In these cases, the needs for intervention are different from those related to individuals serving in prison, particularly in regard to the magnitude of the offenses, the normalization of the offenders' social environment and the fact that many of these batterers live with the victim, even though the judge has issued a restraining or protection order. Today, there are a large number of external institutions that offer intervention programs targeted to batterers with sentence suspension with the collaboration of the Secretary General of Penitentiary Institutions of the Department of the Interior of Spain. Some of these programs are:

1) Galicia Rehabilitation Program for Gender Violence (Arce \& Fariña, 2006, 2007)

2) Therapeutic Program for Aggressors Within the Family (Echavarría, Rodríguez \& Martínez, 2005)

3) Context Program (Lila, 2009, 2010)

4) Psychosocial Offender Program in the Field of Gender Violence (Ruiz \& Expósito, 2008, Expósito \& Ruiz, 2010)
5) Psychosocial Intervention Program for People Who Abuse Their Partners (Quinteros \& Carbajosa, 2008)

6) Psychological Treatment Program for Batterers (Graña, 2008)

These programs are based in different theoretical approaches in addressing gender violence, but the prevailing approach is the cognitive-behavioral orientation. All these programs have admission requirements, such as not to consume toxic substances at a level in which the consumption may hamper the intervention, not to suffer from a severe psychopathological disorder that would interfere with the normal development of the program, not having low intellectual capacity, proficiency in local language, and interest in participating in the program reflected in the commitment to accept a minimum set of rules necessary for the operation of the program (e.g., confidentiality, non-violent behavior, interest in solving the conflicts arising within the group and not to argue or fight outside the group).

Like almost all programs for domestic abusers, the above mentioned have the following therapeutic areas (Martínez García \& Pérez Ramírez, 2009): 1) Acceptance of liability, 2) Empathy and emotional expression, 3) Restructuring of cognitive distortions, 4) Controlling emotions; 5) Development of social and communication skills, and 6) Relapse prevention.

The targeted profile is gender violence offenders with sentence suspension. In addition, these programs are open to individuals that realize that they have problems with their partner and apply for voluntarily or because of the recommendation of a professional, such as a psychologist or a psychiatrist. It should be noted that one of the main problems these programs have to face is voluntariness, since the perpetrator is obliged to attend and complete the intervention program because it is a requirement for sentence suspension. This lack of voluntariness can negatively affect the entire treatment process and its effectiveness (Quinteros \& Carbajosa, 2008; Expósito \& Ruiz Arias, 2010).

In general, programs tend to have 3 stages: (1) initial assessment-diagnosis, (2) treatment, and (3) follow-up. In most cases, the therapeutic stage develops on the basis of the group format, combined, when necessary, with the individual format. The number of participants ranges from 6 to 12. Al- 
most all these programs have an anticipated one-year followup period (see Table 6).

These programs try to last as short as possible. Intervention length ranges between 6 and 18 months. In almost all these programs, a final report is issued (Quinteros, 2010).

\section{INTERVENTION PROGRAMS EFECTIVENESS}

In a review of outcomes of intervention program targeted to batterers involved in domestic violence, Feder et al. (2005, 2008) reported conflicting results. While official reports from experimental studies show a modest benefit, quasi-experimental studies that included a control group of batterers who had not been treated show inconsistent results, suggesting a detrimental overall effect, though minimal (negative effect size). Davis et al., (2000) conducted two intervention programs with an experimental design: one short ( 8 weeks) and the other one long ( 26 weeks). The results showed significantly fewer premature withdrawals in the short program compared with the long one. However, the long program yielded lower rates of recidivism at 6 and 12 months of the follow-up among treated subjects compared to those assigned to the control group, but the difference was not significant when the variable "new incidents reported by the victims" was taken into account. The authors concluded that longer duration of treatment reduces the likelihood of arrests and convictions, and that intervention programs for batterers involved in gender violence have a significant effect in suppressing violent behavior while batterers are under judicial supervision, but this positive effect may disappear when supervision stops (Davis, Taylor \& Maxwel, 2000) Other authors have addressed the disparity of the outcomes (Babcock et al., 2004; Gondolf, 2004; Olver et al., 2011; Eckhardt et al., 2006), and state that conflicting results on outcomes from intervention programs may reflect methodological shortcomings, such as low response rates in surveys to victims and aggressors, too short follow-up periods, lack of assessment of mediating variables, exclusion from evaluations of subjects who did not complete the program, and so on. (Gondolf, 1997; Medina, 2002). A major criterion for assessing whether a program has been successful is the level of recidivism. Due to the absence of control group in some studies and the difficulty that arises in defining the concept of success, since the authors use diverse and broad definitions, is difficult to determine the extent to which a particular treatment is responsible for the decline in the number of aggressions (Sartin, Hansen \& Huss, 2006). Studies carried out by different authors in Spain (Echeburúa \& Fernández-Montalvo, 1997, 2009; Echeburúa, FernándezMontalvo \& Amor, 2006; Echeburúa et al., 2009) have demonstrated the usefulness of intervention programs; however, in Spain, there are no rigorous evaluation reports on the effectiveness, reliability and validity of intervention programs. Echauri has evaluated the effectiveness of intervention program, and has reported a success rate of $45 \%$, an improvement rate of $39 \%$ and a failure rate of $16 \%$ (Echauri, 2010). Other programs mentioned above, such as the Galicia Rehabilitation Program for Gender Violence, and others, like the Navarro Family Institute for Familial Batterers and the Psychosocial Program for Offenders in the Area of Gender Violence of Granada University, have attempted to carry out a comprehensive evaluation of the outcome. Preliminary results suggest that changes in the behavior of batterers are fundamentally related to changing attitudes towards gender violence rather than to true behavioral changes within couple relationship (Lila et al., 2010; Arce \& Fariña, 2006; Ruiz Arias \& Expósito, 2008; Arce \& Fariña, 2010) (see Table 7).

\section{CONCLUSIONS}

Treatment of offenders in the realm of domestic violence is required to control their violent behavior and protect the victims. The intervention programs drop out rate ranges from $50 \%$ to $75 \%$ and recidivism rate varies from $20 \%$ to $60 \%$. These discouraging figures can reflect, aside from other factors, the heterogeneity of the batterer samples and the implementation of standardized programs that do not take into consideration the need to adapt intervention programs to the diverse needs and characteristics of batterers (Loinaz \& Echeburúa, 2010a; Olver, Stockdale \& Wormith, 2011). A number of psychopathological variables, such as psychiatric history, and other variables, like duration of maltreatment, abuse of alcohol and other drugs and duration of treatment, affect the outcome. Therefore, intervention programs should consider the need for parallel, complementary or combined treatments (Boira \& Jodrá, 2010). Consequently, interventions should focus not only on reducing violence, but also in detecting which types and subtypes of batterers could benefit from additional therapeutic programs or customized intervention programs. The duration of intervention programs varies widely, and some authors have stated that they should last at least 4 months and include a follow-up period lasting between 1-2 years (Echeburúa et al., 2004).

While in-prison intervention programs are often voluntary in nature within the rehabilitation goals set for inmates' individualized treatment program, many of the offenders agree to participate in intervention programs for domestic violence because of the penitentiary benefits they can get (e. g., prison stay reduction). Although inconsistent, data suggest that attendance and completeness of imprison intervention programs for domestic violence result in reduction of recidivism of violent acts against the partner (Rosenbaum et al., 2001; Goldman \& Du Mont; 2001).

Some of the most important interpretative and methodological drawbacks are the problems of evaluation and the choice of the most appropriate measurement instruments, since there are not appropriate tests for prison populations (Beven, O’Brien-Malone \& Hall, 2004; Jollife \& Farrington, 2004; Ferrer \& Bosch, 2005). The prison environment is associated with a large number of distinctive factors that should be taken into account in evaluating and measuring program outcomes. Intervention programs conducted in the "normal world" cannot be the same as those conducted in prison, and, therefore, program outcomes cannot be measured and evaluated in the same way. Further studies are needed to: (1) translate, adapt and standardize psychometric tests to be administered to inmates, (2) determine the impact of confounding variables and biases that may affect both treatment and outcome assessments in the setting of the intervention programs targeted to offenders, particularly those convicted of domestic violence, (3) detect and characterize 
Table 6. Intervention for Battered with Suspension of Sentence

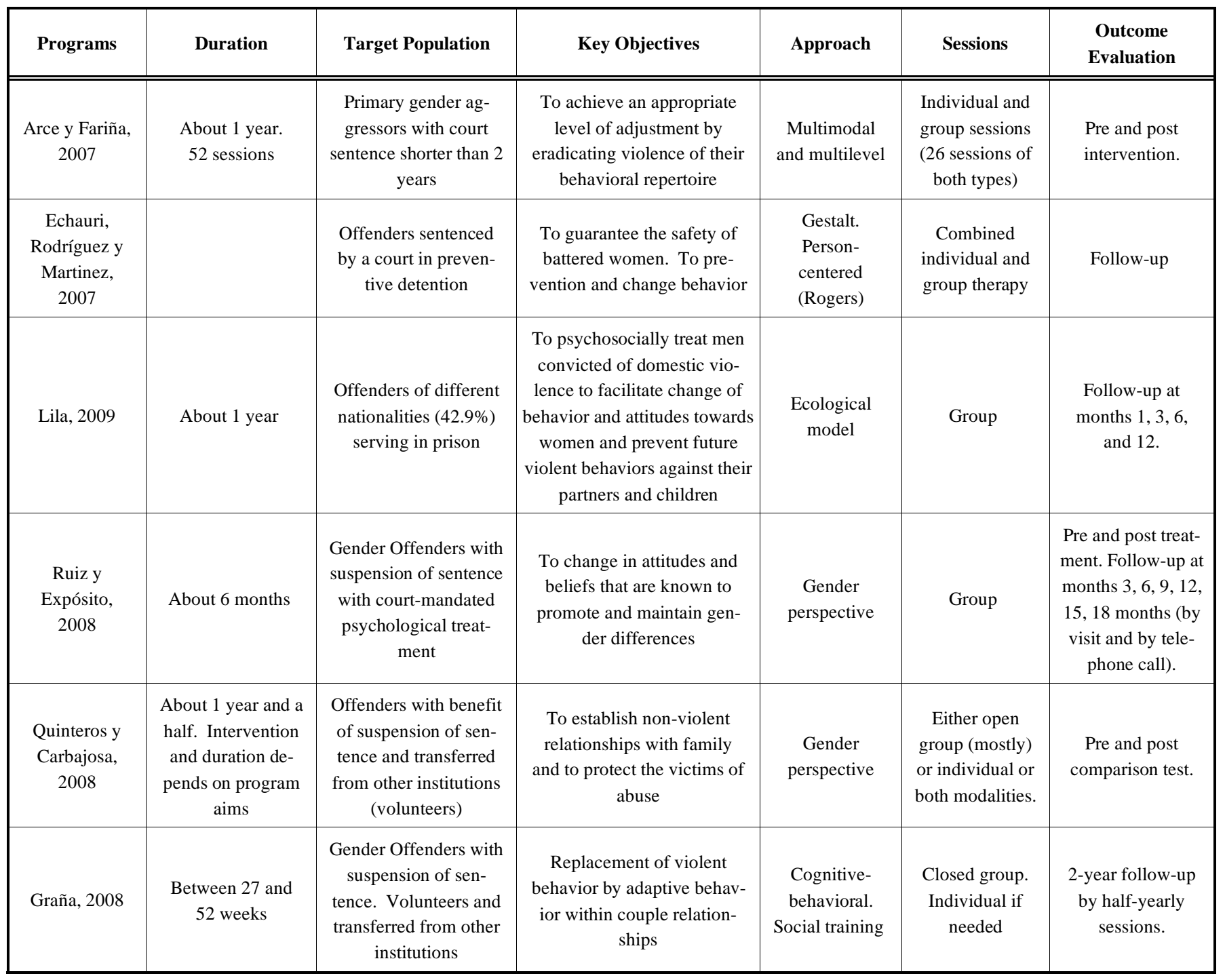

Table 7. Effectiveness of Programs

\begin{tabular}{|c|c|c|c|c|}
\hline Echauri, A. (2010) & $\begin{array}{l}\text { Therapeutic Program for } \\
\text { Offenders in the family } \\
\text { (Echavarría et al., 2007) }\end{array}$ & $\begin{array}{l}250 \text { subjects. } 101 \\
\text { completers }\end{array}$ & $\begin{array}{l}\text { Pre and post treatment } \\
\text { follow-up }\end{array}$ & $\begin{array}{l}45 \% \text { success } \\
39 \% \text { improved } \\
16 \% \text { failure. }\end{array}$ \\
\hline Ruiz \& Expósito (2008) & $\begin{array}{l}\text { Psychosocial Offender } \\
\text { Program in the Field of } \\
\text { Gender Violence }\end{array}$ & $\begin{array}{l}12 \text { subjects with suspen- } \\
\text { sion of sentence }\end{array}$ & Pre and post treatment & $\begin{array}{l}\text { Improvement in distorted thoughts } \\
\text { about women in couple conflict man- } \\
\text { agement and conflict chronicity. } \\
\text { Improvement in impulsivity. }\end{array}$ \\
\hline $\begin{array}{l}\text { Lila, Catalá, et al. } \\
\text { (2010) }\end{array}$ & Context & 210 subjects & $\begin{array}{l}\text { Pre and post treatment } \\
\text { follow-up at months } \\
3,6,9,12,15 \text { and } 18\end{array}$ & $\begin{array}{l}34 \% \text { dropouts. According to prison } \\
\text { social workers, there have been no } \\
\text { relapses are (lack of other informants). }\end{array}$ \\
\hline $\begin{array}{c}\text { Echeburúa \& } \\
\text { Fernandez-Montalvo } \\
\text { (2009) }\end{array}$ & & $\begin{array}{l}148 \text { subjects serving in } \\
\text { Spanish prisons. } 101 \\
\text { completers }\end{array}$ & Pre and post treatment & $\begin{array}{l}38.1 \% \text { dropouts. Improvement in } \\
\text { cognition, negative attitudes about } \\
\text { women and conflict solving. Im- } \\
\text { provement in rage and impulsivity } \\
\text { control and self-esteem. Reduction in } \\
\text { psychopathology. }\end{array}$ \\
\hline
\end{tabular}


(Table 7) contd....

\begin{tabular}{|c|c|c|c|c|}
\hline $\begin{array}{l}\text { Echeburúa, Sarasua } \\
\text { et al., (2009) } \\
\text { Assessment in a } \\
\text { community }\end{array}$ & & 196 subjects & $\begin{array}{l}\text { Pre and post treatment } \\
\text { and follow-up at months } \\
\qquad 1,3,6 \text { and } 12\end{array}$ & $\begin{array}{l}88 \% \text { success rate in subjects who } \\
\text { completed the treatment } 46 \% \\
\text { loss of patients. }\end{array}$ \\
\hline $\begin{array}{c}\text { Echeburúa \& } \\
\text { Fernandez-Montalvo } \\
\text { (2006) }\end{array}$ & & $\begin{array}{l}52 \text { subjects serving in } 8 \\
\text { Spanish prisons }\end{array}$ & Post-treatment & Significant improvement. \\
\hline $\begin{array}{c}\text { Echeburúa \& } \\
\text { Fernandez-Montalvo } \\
\text { (1997) }\end{array}$ & & 16 subjects & At months 1 and 3 & $\begin{array}{l}48 \% \text { of therapeutic rejection at the } \\
\text { beginning of the program. }\end{array}$ \\
\hline $\begin{array}{c}\text { Martínez García \& } \\
\text { Pérez Ramírez (2009) }\end{array}$ & $\begin{array}{l}\text { In-Prison Program for } \\
\text { Men Who have Commit- } \\
\text { ted Violence Against } \\
\text { Women (VIDO program } \\
\text { for prison under the juris- } \\
\text { diction of the Catalonia } \\
\text { Government) }\end{array}$ & $\begin{array}{l}28 \text { men in three groups. } 2 \\
\text { groups had a short inter- } \\
\text { vention program and } 1 \\
\text { had a long one }\end{array}$ & $\begin{array}{l}\text { Intragroup design with pre } \\
\text { and post treatment evalua- } \\
\text { tion }\end{array}$ & $\begin{array}{l}\text { Significant differences in the scores of } \\
\text { the Impulsivity Scale BISS11 and } \\
\text { STAXI Anger Scale 2. Reduction in } \\
\text { unplanned impulsive. No impact on } \\
\text { criminological variables under study. }\end{array}$ \\
\hline
\end{tabular}

batterers serving in prison due to domestic violence who are prone to prematurely withdraw from intervention programs, including the reasons why they withdraw, (4) include ethnic/cultural aspects in the intervention programs (to our knowledge, only one intervention program now conducted in Spain includes ethnic/cultural considerations), and (5) assess the level of improvement and satisfaction as reported by the victims. It should borne in mind that the ultimate goal of intervention programs for domestic batterers is to reduce or eradicate the maladaptive behaviors in order to prevent further violence acts and protect the safety of battered women.

\section{ACKNOWLEDGEMENT}

None.

\section{CONFLICT OF INTEREST}

None.

\section{REFERENCES}

Arce, R. \& Fariña, F. (2006). Programa Galicia de reeducación para maltratadores de género. Anuario de Psicología Jurídica, 16, 41-64.

Arce, R. \& Fariña, F. (2007). Intervención psicosocial con maltratadores de género. En: Sabucedo y SanMartín (Ed.) Los escenarios de la violencia. Barcelona, Ariel.

Arce, R.; Fariña, F. (2010). Diseño e implementación del programa Galicia de reeducación de maltratadores. Una respuesta psicosocial a una necesidad social y penitenciaria. Intervención psicosocial, 19, 153-166.

Asociación de mujeres por la inserción laboral (SURT) (2007). Abordando la violencia de género en prisión. Manual de programas penitenciarios contra la violencia de género. Barcelona: SURT.

Babcock, J. C. Green, C. E. \& Robie, C. (2004). Does batterer' treatment work? A meta-analytic review of domestic violence treatment. Clinical Psycholgy Review, 23, 1023-1053.

Beven, J. P., O’Brien-Malone, A. \& Hall, G. (2004). Using the interpersonal reactivity index to assess empathy in violent offenders. International Journal of Forensic Psychology, 1 (2), 33-41.

Boira, S. \& Jodrá, P. (2010). Psicopatología, características de la violencia y abandonos en programas para hombres violentos con la pareja: resultados en un dispositivo de intervención. Psicothema, 22 (4), 593899.

Castillo, T.; Estepa, Z.; Guerrero, J.; Rivera, G.; Ruiz, A.; Sánchez, C. (2005). Programa de tratamiento en prisión para agresores en el ámbito familiar. Ministerio del interior, Dirección General de Instituciones Penitenciarias. Documento Penitenciario, 2.
Davis, R.C.,Taylor,B. G. \& Maxwel, D. (2000). Does batterer treatment reduce violence. A randomized experiment in Brooklyn. From http://www.ncjrs.gov/pdffiles1/nij/grants/180772. (Consultado el 21/3/11).

Dutton, D. G. and Golant, S. K. (1997). El golpeador. Un perfil psicológico. Barcelona, Paidós.

Dutton, D. G., Bodnarchuk, M., Kropp, R., Hart, S. D. \&Ogloff, J. P. (1997). Client personality disorders affecting wife assault posttreatment recidivism. Violence Victims, 12 (1), 37-50.

Dutton, DG, Van-Gimkel, C. \& Landolt, M. A. (1996). Jealously, intimate abusiveness and intrusiveness. Journal Family Violence, 11, 411-423.

Echauri, A. (2010). Eficacia de un programa de tratamiento psicológico para hombres maltratadores en la relación de pareja. Características psicopatológicas y resultados terapéuticos. Tesis doctoral, Universidad de Navarra.

Echauri, J. A.; Romero, J.; Rodríguez de Armenta, M. J. (2005). Teoría y descripción de la violencia doméstica. Programa terapéutico para maltratadores del ámbito familiar en el centro penitenciario de Pamplona. Anuario de Psicología Jurídica, 15, 67-95.

Echeburúa, E. \& De Corral, P. (1998). Manual de Violencia Familiar. Madrid: Siglo XXI.

Echeburúa, E. \& Fernández-Montalvo, J. (1997). Tratamiento cognitivoconductual de hombres violentos en el hogar: un estudio piloto. Análisis y Modificación de Conducta, 23(89), 355-384.

Echeburúa, E. \& Fernández-Montalvo, J. (2009). Evaluación de un programa de tratamiento en prisión de hombres condenados por violencia grave contra la pareja. International Journal Clinical and Health Psychology, 9(1), 5-20.

Echeburúa, E. Sarasua, B., Zubizarreta, I. \& de Corral, P. (2009). Evaluación de la eficacia de un tratamiento cognitivo-conductual para hombres violentos contra la pareja en un marco comunitario: una experiencia de 10 años (1997-2007). International Journal Clinical and Health Psychology, 9 (2), 199-217.

Echeburúa, E., de Corral, P., Fernánder-Montalvo, J. \& Amor, P. J. (2004). ¿Se puede y debe tratar psicológicamente a los hombres violentos contra la pareja? Papeles del Psicólogo, 88, 20-28.

Echeburúa, E., del Corral, P. \& Amor, P. J. (1999). Violencia familiar. Madrid, Fundación Universidad-Empresa.

Echeburúa, E., Fernández-Montalvo, J. \& Amor, P. J. (2006) Psychological treatment of men convicted of gender violence. A pilot study in Spanish prisons. International Journal of Offender Therapy and Comparative Criminology, 50(1), 57-70.

Echeburúa, E.; Amor, P. J.; Fernández-Montalvo, J. (2007). Vivir sin violencia. Pirámide.

Eckhardt, C. I., Murphy, C., Black, D. \& Suhr, L. (2006). Intervention programs for perpetrators of intimate partner violence. Conclusions from a clinical research perspective. Public Health Reports, 121, 369-381.

Expósito, F.; Ruiz Arias, S. (2010). Reeducación de maltratadores: una experiencia de intervención desde la perspectiva de género. Intervención psicosocial, 19, 145-151. 
Feder, L. \& Wilson, D. B. (2005). A meta-analytic review of courtmandated batterer intervention programs: can courts affect abusers' behavior. Journal of Experimental Criminology, 1, 239-262.

Feder, L., Wilson, D. B. \& Austin, S. (2008). Court-mandated interventions for individuals convicted of domestic violence. A Campbell Collaboration Systematic Review, 12, 1-46.

Ferrer, V. A. \& Bosch, E. (2005). Introduciendo la perspectiva de género en la investigación psicológica sobre violencia de género. Anales de Psicología, 21(1), 1-10.

Goldman, J. \& Du Mont, J. (2001). Moving forward in batterer program evaluation: posing a qualitative, woman-centered approach. Evaluation and Program Planning, 24, 297-305.

Gondolf, E. W. (1997). Batterer programs: What we know and need to Know. Journal of Interpersonal Violence, 12, 83-89.

Gondolf, E. W. (2004). Evaluating batterer counseling programs. A difficult task showing some effects and implications. Aggressive and Violent Behaviour, 9, 605-631.

Holtzworth-Munroe, A. \& Stuart, G. L. (1994). Typologies of male batterers: Three subtypes and the differences among them. Psychological Bulletin, 116 (3), 476-497.

Holtzworth-Munroe, A., Meehan, J. C., Herron, K., Rehman, U. \& Stuart, G. L. (2000). Testing the Holtzworth-Munroe and Stuart (1994). Batterer Typology. Journal of Consulting and Clinical Psychology, 68(6), 1000-1019.

Instituto de la Mujer (2006). Tercera macro-encuesta sobre la violencia contra las mujeres, Spain. Informe de resultados.

Jacobson, N. \& Gottman, J. (2001). Hombres que agreden a sus parejas. Cómo poner fin a las relaciones abusivas. Barcelona, Paidós.

Jewell, L. M. \& Wormith, J. S. (2010). Variables associated with attrition from domestic violence treatment programs targeting male batterers. Criminal Justice and Behaviour, 37(10), 1086-1113.

Jollife, D. \& Farrington, D. P. (2004). Empathy and offending: A systematic review and meta-analysis. Aggression and Violent Behaviour, 9, 441-476.

Ley Orgánica 1/1979 de 26 de Septiembre, General Penitenciaria. Boletín Oficial del Estado Español (BOE) de 5 de octubre, número 239.

Ley Orgánica I/2004 de 28 de Diciembre, de Medidas de protección integral contra la violencia de género. Boletín Oficial del Estado Español (BOE) de 29 de Diciembre de 2004.

Lila, M. (2009). Intervención con hombres penados por violencia contra la mujer. El programa Contexto. En Fariña, Arce, Buela-Casal (Eds) Violencia de género. Tratado psicológico y legal. Madrid, Biblioteca nueva.

Lila, M., Catalá, A., Conchell, R. García, A., Lorenzo, M. V. Pedrón, V. \& Terreros, E. (2010). Una experiencia de investigación, formación e intervención con hombres penados por violencia contra la mujer en la Universidad de Valencia: programa Contexto. Intervención Psicosocial, 19(2), 167-179.

Loinaz, I. \& Echeburúa, E. (2010a). Necesidades terapéuticas en agresores de pareja según su perfil diferencial. Clínica Contemporánea, 1(2), 82-95.

Loinaz, I., Echeburúa, E. \& Torrubia, R. (2010b) Tipología de agresores contra la pareja en prisión. Psicothema, 22(1), 106-111.

Loinaz, I., Torrubia, R. Eheburúa, E., Navarro, J. C. \& Fernández, L. (2009). Implicaciones de las tipologías de agresores de pareja para el tratamiento en prisión. Cuadernos de Medicina Psicosomática y Psiquiatría de Enlace, 91, 19-25.

Madina, J. (1994). Perfil psicosocial y tratamiento del hombre violento con su pareja en el hogar. En E. Echeburúa (Ed.). Personalidades violentas. Madrid: Pirámide.

Martínez García, M. \& Pérez Ramírez, M. (2009). Evaluación criminológica y psicológica de los agresores domésticos. Generalitat de Cataluña. Departamento de Justicia. Centro de Estudios Jurídicos y Formación Especializada.

Medina, J. J. (2002). Violencia contra la mujer en la pareja: Investigación comparada y situación en España. Valencia, Tirant lo Blanch.

Ministerio de Sanidad, Política Social e Igualdad (2010a). Información estadística de violencia de género. Informe mensual. Government of Spain: Octubre 2010.

Ministerio de Sanidad, Política Social e Igualdad, Spain (2010). Tercer informe anual del observatorio estatal de violencia sobre la mujer. Colección documentos contra la violencia de género.
Olver, M. E. Stockdale, K. C. \& Wormith, J. S. (2011). A meta-analysis of predictors of offender treatment attrition and its relationship to recidivism. Journal of Consulting and Clinical Psychology, 79(1), 6-21.

Olver, M. E., Stockdale, K. C. \& Wormith, J. S. (2011). A meta-analysis of perdictors of offender treatment attrition and its relationship to recidivism. Journal of Consulting and Clinical Psychology, 79(1), 6-21.

Ortiz, A. \& García, E. (2003). Violencia doméstica. Modelo de análisis y programas de intervención con agresores. Cuadernos de Trabajo Social, $16,193-214$.

Pérez del Campo, A. M. (1995). Una cuestión incomprendida. El maltrato a la mujer. Madrid.

Quinteros, A. (2010). Tratamiento psicológico a hombres que ejercen violencia de género: criterios básicos para elaborar un protocolo de intervención. Clínica Contemporánea, 1(2), 129-139.

Quinteros, A.; Carbajosa, P. (2008). Hombres Maltratadores. Tratamiento psicológico de agresores. Acebo, Grupo 5.

Real Decreto 1849/2009, por el que se modifica el Real Decreto 515/2005. Boletín Oficial del estado Español (BOE) número 293 de 5 de Diciembre de 2009.

Real Decreto 190/1996 de 9 de Febrero por el que se aprueba el Reglamente Penitenciario. Boletín Oficial del Estado español (BOE) de 15 de Febrero, número 40.

Real Decreto 515/2005 de 6 de mayo por el que se establecen las circunstancias de ejecución de las penas de trabajos en beneficio de la comunidad y de localización permanente, de determinadas medidas de seguridad, así como de la suspensión de la ejecución de las penas privativas de libertad. Boletín Oficial del Estado Español (BOE) número 109 de 7 de mayo.

Redondo, N., Graña, J. L. \& Cieza, J. L. (2009). Características sociodemográficas y delictivas de maltratadores en tratamiento psicológico. Psicopatología Clínica, Legal y Forense, 9, 49-61.

Redondo, S \& Garrido, V. (1999). Propuesta para el tratamiento en la comunidad de los agresores intrafamiliares. Barcelona.

Rosenbaum, A., Gearan, P., Ondovic, C. \& Geffner, R. (2001). Completion and recidivism among court -and self-referred batterers in a psychoeducational group treatment program: implications for intervention and public policy. Journal of Aggression Maltreatment \& Trauma, 5(2), 199-220.

Ruiz Arias, S. \& Expósito, F. (2008). Intervención con hombres en suspensión condicional de condena por violencia de género. Anuario de Psicología Jurídica, 18, 81-89.

Ruiz, S., Negredo, N., Ruiz, A., Garcia-Moreno, C., Herrero, O., Yela, M. Pérez, M. (2010). Violencia de género: programa de intervención con agresores (PRIA). Ministerio del Interior, Secretaria General de Instituciones Penitenciarias. Documento Penitenciario 7.

Russell, M. N, Lipoy, E., Phillips \& White, B. (1989). Psychological profiles of violent and non-violent martially distressed couples. Psychotherapy, 26(1), 81-87.

Sanmartín, J., Iborra, I., García Esteve, Y. \& Martínez Sánchez, P. (2010). 3RD international report partner violence against women statistics and legislation. Serie documentos 16.

Sartin, R. M., Hansen, D. J. \& Huss, M. T. (2006). Domestic violence treatment response and recidivism: A review and implications for the study of family violence. Aggressive and Violent Behaviour, 11, 425-440.

Simon, L. M. J. A. (1995). Therapeutic jurisprudence approach to the legal processing of domestic violence cases. Psychology Public Policy and Law, 1(1), 43-79.

Spanish Ministry of Equality (2010). Balance of evolution followed by gender-based violence. January-June 2010.

Stuart, G. L., Temple, J. R., Follansbee, K. W., Bucossi, M. M. Hellmuth, J. C. \& Moore, T. M. (2008). The role of drug use in a conceptual model of intimate partner violence in men and women arrested for domestic violence. Psychology and Addictive Behaviors, 22(1), 12-24.

United Nations (1993). Declaration on the Elimination of Violence against Women. General Assembly resolution 48/104 of 20 December 1993.

United Nations (1995). Report of the Fourth World Conference on Women. Beijing.

World Health Organization (2005). Multi-country study by WHO on Women's health and domestic violence. 